\title{
Antimalarial and anticancer properties of artesunate and other artemisinins: current development
}

\author{
Pitambar Khanal ${ }^{1} \mathbb{D}$
}

Received: 30 December 2020 / Accepted: 22 March 2021 / Published online: 30 March 2021

(c) Springer-Verlag GmbH Austria, part of Springer Nature 2021

\begin{abstract}
This review provides a recent perspective of artesunate and other artemisinins as antimalarial drugs and their uses in cancer therapy. Artesunate is an artemisinin derivative. Artemisinin is extracted from the plant Artemisia annua. Artemisinin and its derivatives have been the most useful drug for malarial treatment in human history. The artesunate has an advantage of a hydrophilic group over other artemisinins which makes it a more potent drug. On the industrial scale, artemisinins are synthesized in semisynthetic ways. The 1,2,4-endoperoxide bridge of artemisinins is responsible for the drug's antimalarial activity. There is the emergence of artemisinin resistance on Plasmodium falciparum and pieces of evidence suggest that it is mainly due to the mutation at Kelch13 protein of P. falciparum. Clinical trial data show that the artesunate is more favorable than quinine and other artemisinins to treat patients with severe malaria. Pieces of evidence indicate that artemisinins can be developed as anticancer drugs. The mechanism of actions on how artemisinins act as an anticancer drug involves oxidative stress, DNA damage and repair, and various types of cell deaths.
\end{abstract}

\section{Graphic abstract}

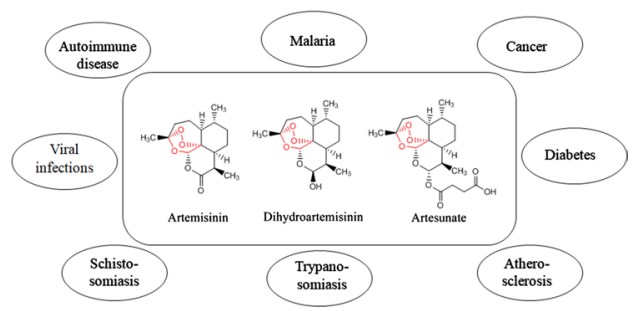

Keywords Artemisinins $\cdot$ Plasmodium falciparum $\cdot$ Anticancer drug $\cdot$ Antimalarial drug

\section{Introduction}

Artemisinins are derived from the extracts of sweet wormwood (Artemisia annua) in the 1970s, a Chinese herbal remedy that had been used to treat fever for almost 2000 years [1]. The Nobel Prize of Physiology or Medicine of 2015 was awarded to Youyou Tu for her discovery and continuous research on artemisinins. Youyou did a search on ancient literature and developed a purification method, i.e., extraction

Pitambar Khanal

pitambar.khanal@gmail.com

1 Nagarik College, Tribhuvan University, Gaidakot-2, Nawalparasi Purva, Gandaki, Nepal with cold ether, conducted clinical trials-first in mice and monkey models, and then in humans [2].

When extracting from the plant, the best yield of artemisinin was up to $0.6 \%$. The extraction was done using petroleum ether of leaves and flowering top of $A$. аппиа. The detection of artemisinin in the crude extract is difficult but crucial; the NMR spectroscopy can be used for the simultaneous determination of artemisinin and its analog flavonoids in Artemisia апnиа crude extracts [3].

After the discovery of artemisinin (Fig. 1), its derivatives were synthesized, these derivatives are collectively termed artemisinins. The reduction of a keto group in artemisinin gives dihydroartemisinin (DHA), converting DHA into 
methyl and ethyl ether gives the artemether and the arteether, respectively.

The bioactivities of artemisinins are not restricted only to malaria. It is being studied in a wide range of diseases such as cancer, diabetes, atherosclerosis, trypanosomiasis, schistosomiasis, viral infections, autoimmune diseases, etc (Fig. 2) [4].

Artesunate is a small molecule, a hydrophilic derivative of artemisinin; a sesquiterpene trioxane lactone peroxide. It has a chemical formula of $\mathrm{C}_{24} \mathrm{H}_{39} \mathrm{O}_{8}$ and a molecular weight

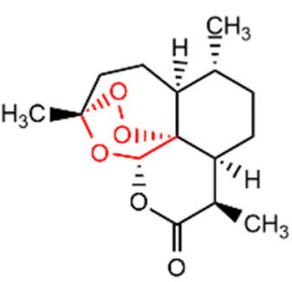

Artemisinin

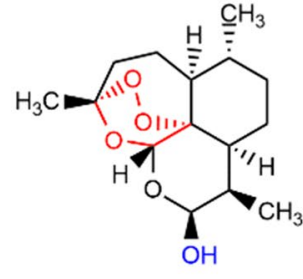

Dihydroartemisinin

of $455.56 \mathrm{~g} / \mathrm{mol}$. Figure 3 shows structures of two commonly used severe anti-malarial drugs artesunate and quinine.

\section{Synthesis}

When extracting from the plant, the yield of artemisinin is very low, hence there is a need for synthetic or semisynthetic pathways for its industrial-scale production. The biosynthetic pathway of the formation of artemisinin in

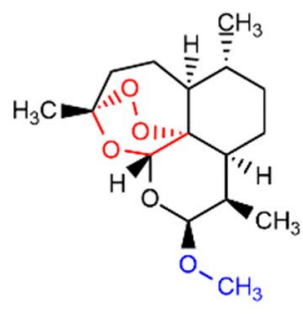

Artemether

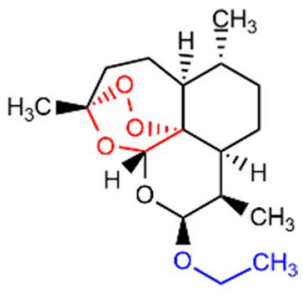

Arteether

Fig. 1 Artemisinin and other commonly used artemisinin derivatives having antimalarial and anticancer properties

Fig. 2 Bioactivities of artemisinin and its derivatives
Fig. 3 Structure of artesunate and quinine; two important severe anti-malaria drugs
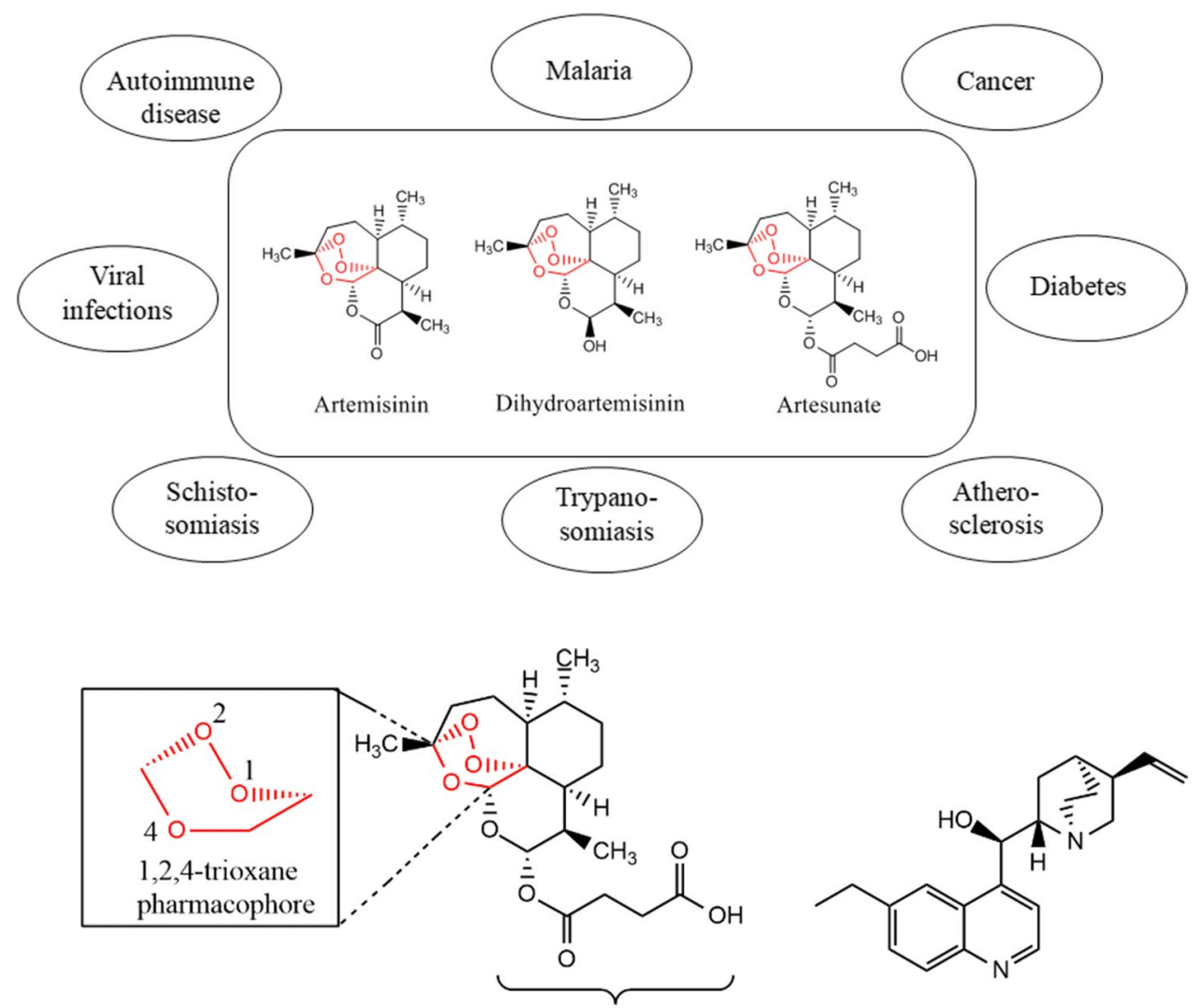<smiles>C=C[C@H]1CN2CC[C@H]1C[C@H]2[C@H](O)c1ccnc2ccc(CC)cc12</smiles>

Hydrophilic part increases water solubility

\section{Quinine}

Artesunate 
Artemisia annua L. starting mevalonic acid is shown in Scheme 1 [5].

The key intermediate to produce artemisinin in this biosynthetic pathway is dihydroartemisinic aldehyde. The control of stereocenter $\alpha$ to the aldehyde in dihydroartemisinic aldehyde is a challenging task. Zanetti et al. [6] developed a method that allows diastereomeric enrichment of a mixture of $(11 \mathrm{R}) /(11 \mathrm{~S})$ to the desired (11R) using the Betti base in a crystallization induced diastereomeric transformation (Scheme 2).

Since total syntheses have not given a good yield, the commercial synthesis is done with partial synthesis with

\section{Scheme 1}

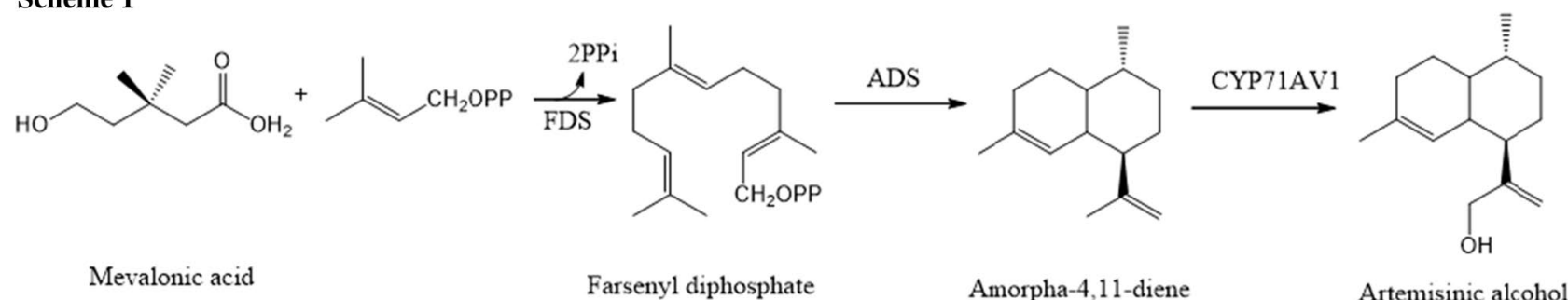

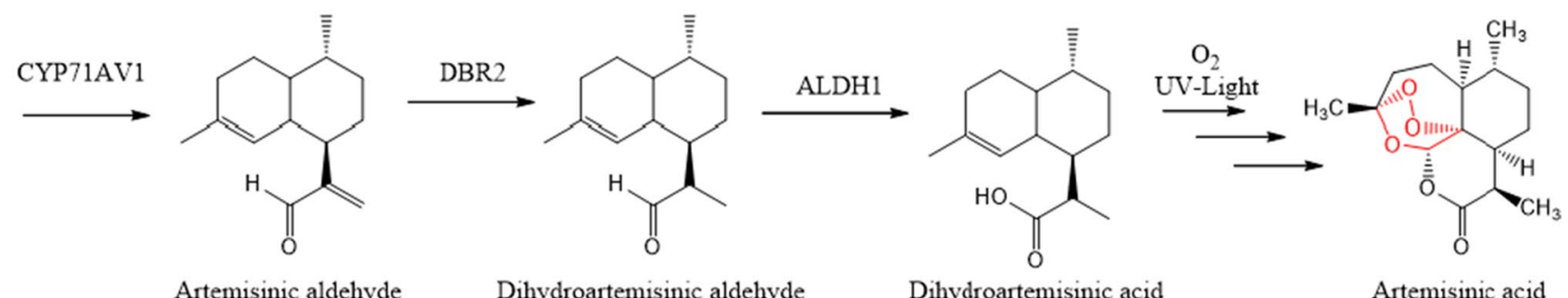

Scheme 2

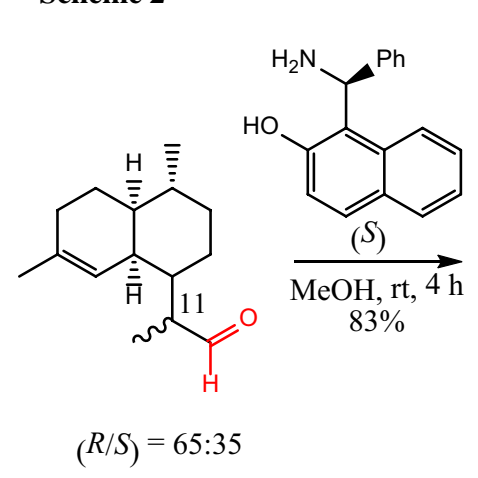

Dihydroartemisinic aldehyde

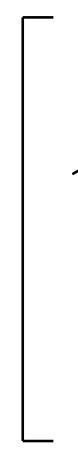<smiles>CC1=C[C@H]2[C@H]([C@H](C)C3N[C@@H](c4ccccc4)c4c(ccc5ccccc45)O3)CC[C@@H](C)[C@H]2CC1</smiles><smiles>CC1=C[C@@H]2[C@H](CC1)[C@H](C)CC[C@H]2[C@@H](C)C1N[C@@H](c2ccccc2)c2c(ccc3ccccc23)O1</smiles>

Naphthoxazine $72: 28$<smiles>CC1=C[C@]2(C)[C@@H](C)CC[C@@H](C)[C@H]2CC1</smiles>

$(R / S)=95: 5$

Dihydroartemisinic aldehyde aq. $2 \% \mathrm{TsOH}\left(0.2 \mathrm{~cm}^{3} / \mathrm{mmol}\right)$

Dowex 50WX8-100 (2 g/mmol)

THF/ETOAc (1:1), rt, $14 \mathrm{~h}$ quant.

Artemisinic acid 
another Artemisia plant extract artemisinic acid that increases total yield up to 32\% (Scheme 3) [7].

To quantify the non-enzymatic conversion of dihydroartemisinic acid into artemisinin, Varela et al. [8] developed a method using LC-MS. It was found that the rate of conversion of 3,3-dideuteroartemisinin from 3,3-dideuterodihydroartemisinic acid was $1400 \mathrm{ng} /$ day and $32 \mathrm{ng} /$ day in the presence and absence of light, respectively. In the process, they also observed the mixture of 3-deuteroartemisinin and artemisinin (Scheme 4).

The mechanism of conversion of dihydroartemisinic acid into artemisinin has been studied [9] and it is believed that the singlet oxygen is used for the conversion of dihydroartemisinic acid to allylic hydroperoxide intermediate and the triplet oxygen in the conversion to artemisinin (Scheme 5).

To produce artemisinin on large scale, various total syntheses were carried out mainly with the terpene starting material but there were problems of yield and scalability. Zhu and Cook carried out a fully synthetic approach starting with cyclohexenone [10]. Artemisinin was obtained in eight steps with $13 \%$ of the overall yield on a gram scale (Scheme 6).
Turconi et al. published a Sanofi Pasteur's new process chemistry from conversion of artemisinic acid to artemisinin in 55\% overall yield [11] (Scheme 7).

Synthesis of artesunate from artemisinin can be done by reducing artemisinin into DHA using $\mathrm{NaBH}_{4}$ in $\mathrm{MeOH}$ (Scheme 8). The acylation of DHA into artesunate can be done by treating with succinic anhydride in the presence of a base such as diisobutylaluminium hydride (DIBAL) [12].

\section{Antimalarial properties}

More than 400,000 people are killed each year by falciparum malaria and the majority of which are African children [13]. The United States Food and Drug Administration (FDA) approved the artesunate on May 26, 2020, as the first line of treatment for children or adults with severe malaria. When infected with falciparum malaria, a non-immune individual is mostly affected. The mortality rate is $5-10 \%$, and in severe cases, multiple organs could be affected. The drug of choice for malaria for almost 400 years is cinchona alkaloid, the quinine [14]. However, with the discovery of artemisinin and its derivatives, the drug of choice has been changing.

Scheme 3<smiles>C=C(C(=O)O)C1CC[C@H](C)[C@H]2CCC(C)=C[C@H]12</smiles>

Artemisinic acid

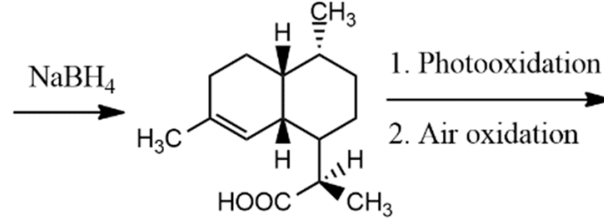

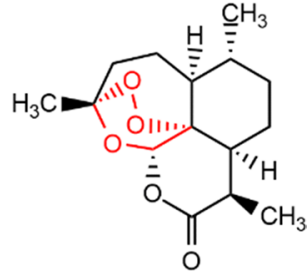

Artemisinin

Scheme 4

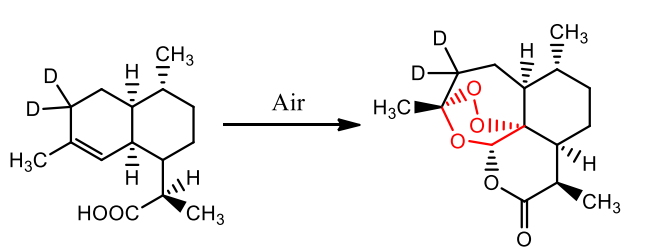

3,3-Dideuterodihydroartemisinic acid

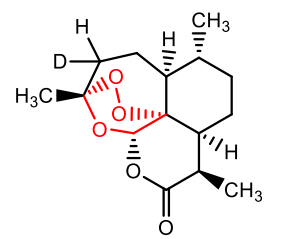




\section{Scheme 6}

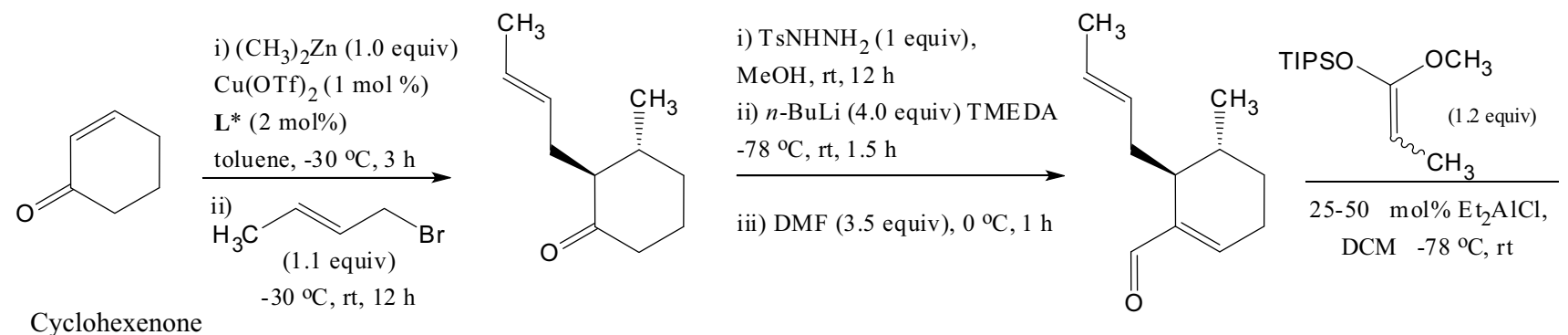<smiles>C/C=C/C[C@H]1C2=COC(OC)(OC)C(C)C2CC[C@@H]1C</smiles>

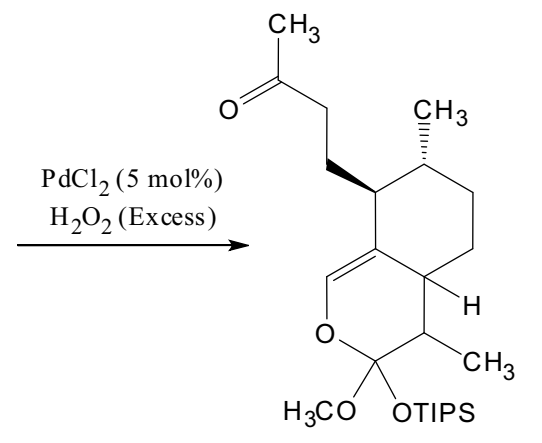

i) $\left(\mathrm{NH}_{4}\right)_{2} \mathrm{MoO}_{4}(0.2-1$ equiv) $\mathrm{H}_{2} \mathrm{O}_{2}$ (excess) $t-\mathrm{BuOH}, \mathrm{rt}, 3 \mathrm{~d}$

ii) $p$-TSA (10 mol\%), DCM, rt, $3 \mathrm{~d}$

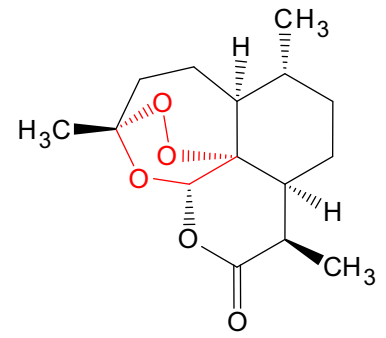

Artemisinin<smiles>CC[C@H](c1ccccc1)N([C@H](CC)c1ccccc1)p1oc2ccccc2c2ccccc2o1</smiles>

\section{Scheme 7}<smiles>C=C(C(=O)O)[C@H]1CC[C@@H](C)[C@H]2CCC(C)=C[C@H]12</smiles>

Artemisinic acid
$\mathrm{Rucl}_{2}[(\mathrm{R})$-dtbm-Segphos](DMF) $\mathrm{S} / \mathrm{C}>8000 / 1$

$\mathrm{MeOH}, \mathrm{Et}_{3} \mathrm{~N}, 22 \mathrm{bar} / 5-6 \mathrm{~h}$ $99 \%$ 


\section{Scheme 8}

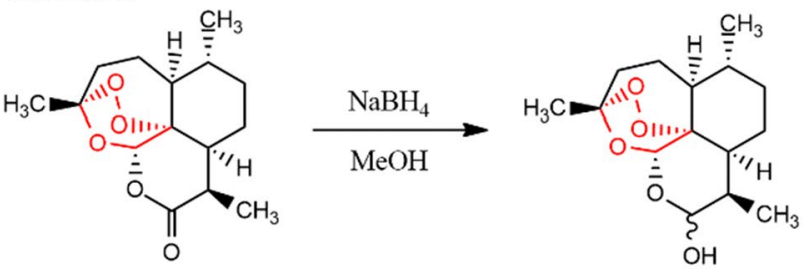

Artemisinin<smiles>C[C@@H]1CC[C@H]2[C@@H](C)[C@H](O)O[C@@H]3O[C@]4(C)CC[C@@H]1[C@@]23OO4</smiles><smiles></smiles>

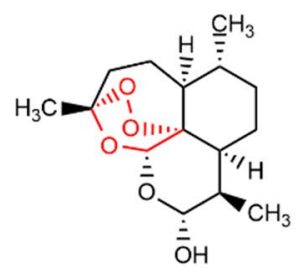

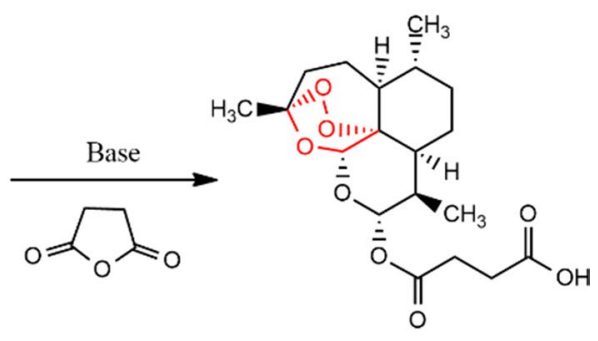

Artesunate
There is growing interest in medicinal chemistry about artemisinins, as this class of antimalarial drugs is the most effective drug against $P$. falciparum. Tiwari and Chaudhary [15] published a recent review on artemisinins describing broadly the synthetic part, this review serves as a complementary to that review covering the recent development of medicinal as well as the synthetic area.

Currently, artemisinin and its derivatives are one of the most widely used drugs in the world and the most useful malarial treatment drugs. Artemisinin derivatives are parasitocidal, kill young circulating parasites which prevent parasites' further maturation and sequestration [16]. Artemisinins also have potent anti-cancer properties [17], they have antiproliferative effects against a wide range of cancer cell lines [18]. Artemisinins, in particular, dihydroartemisinin (DHA) can inhibit some cancer cells [19].

Serious pathology in falciparum malaria causes endorgan damage due to mature and parasitized red blood cells sequestering in capillary beds. In comparison with quinine, the artesunate acts on all stages of malaria parasite circulation, while quinine works only at a mature trophozoite stage [20].

In severe cases, artesunate is given as a parenteral route either intravenous (IV) or intramuscular (IM). The IV route is preferred, because in severe cases in the IM route capillary sequestration may delay drug absorption. Artesunate can also be given as a rectal route for a person with severe malaria by trained community health volunteers before referral to healthcare facilities. In a study conducted in Zambia [21], it was found that rectal
Table 1 Antiplasmodial activity and cytotoxicity $\left(\mathrm{IC}_{50} / \mu \mathrm{m}\right)$ of natural $(+)$-artemisinin and its synthetic enantiomer (-)-artemisinin

\begin{tabular}{|c|c|c|c|c|}
\hline \multirow[t]{2}{*}{ Compound } & \multicolumn{2}{|l|}{ P. falciparum } & \multicolumn{2}{|c|}{ Mammalian cell lines } \\
\hline & NF54 & $\mathrm{L}-6^{\mathrm{a}}$ & $\begin{array}{l}\text { CCRF- } \\
\text { CEM }^{\text {b }}\end{array}$ & $\begin{array}{l}\text { CEM/ } \\
\text { ADR500 }\end{array}$ \\
\hline $\begin{array}{c}(+) \text {-Arte- } \\
\text { misinin }\end{array}$ & $0.009 \pm 0.001$ & $>350$ & $36.90 \pm 6.90$ & $26.90 \pm 4.40$ \\
\hline $\begin{array}{r}(-) \text {-Arte- } \\
\text { misinin }\end{array}$ & $0.011 \pm 0.005$ & $188 \pm 21$ & $55.54 \pm 7.00$ & $45.41 \pm 8.06$ \\
\hline
\end{tabular}

${ }^{a}$ A primary cell line derived from rat skeletal myoblasts

${ }^{\mathrm{b}}$ An artemisinin-sensitive human leukemia cell line

${ }^{\mathrm{c}}$ A multidrug-resistant human leukemia cell line

route administration reduces the fatality rates in young children.

On a different note, Krieger et al. synthesized synthetic enantiomer, (-)-artemisinin, and showed that the antimalarial activity of artemisinin is not stereospecific (Table 1) [22].

\section{Mechanism of action}

ART combination therapy (ACT) is mostly used to combat $P$. falciparum infections. There is the emergence of a decrease in sensitivity of ARTs which makes it critically important to understand its mechanism of action. Bridgford et al. used ART derivative, dihydroartemisinin (DHA) to show parasite killing via a two-pronged mechanism one by 
protein damage and the other by inhibiting the proteasome [23].

The mechanism of action is not entirely known. The 1,2,4-endoperoxide bridge is responsible for the drug's antimalarial activity. In the asexual life cycle, parasite survival is possible only when it digests hemoglobin and multiplication of $P$. falciparum in red blood cells [18].

The study has found that deoxyartemisinins that lack an endoperoxide bridge, have no ROS production effect in malarial mitochondria, while artemisinins are distributed in malarial mitochondria and impaired their functions [24]. Bonepally et al. studied by synthesizing tetracyclic peroxide and 6-aza-artemisinins and found that moderate to almost negligible anti-malarial activities in the modification of skeletal arrays, functional groups, and the peroxide bridge [25].

It is known that mammalian cells are not sensitive to ARTs but the malarial mitochondria are highly sensitive. ARTs are permeable to the cell membrane. ARTs react with hem, generating reactive oxygen species (ROS), a potentially damaging agent. A fraction of ARTs gets into the mitochondria of a parasite, where they react to each other and result in mitochondrial dysfunction. In the case of mammalian cells, a little mitochondrial effect was observed. Depolarization of the malarial mitochondria occurs in less than two minutes after the addition of drugs [18]. The oxidative stress caused by artemisinins acts on lipids as well as widespread damage to the parasite proteins in different cellular compartments. As a result polyubiquitination of the damaged protein occurs then it is degraded by the proteasome [26].

The digestion of host hemoglobin gives the malaria parasite rich in hemin. Toxic oxygenated byproducts may be formed by reacting artemisinins with hemin within the parasite [27].

To predict the resistance mechanism, the understanding of the mechanism of action of endoperoxide pharmacophore is necessary that helps to design future anti-malarial drugs.
There are suggestions for two models of endoperoxide ringopening. The ring-opening differs in their dependency on iron and the involvement of carbon-centered radicals. (A) Open peroxide model: in the open peroxide model, ringopening occurs either by complexation with $\mathrm{Fe}^{2+}$ or by protonation. (B) Reductive scission model. In the reductive scission model, carbon-centered radicals are formed from oxygen-centered radicals after the rearrangement. Primary or secondary carbon-centered radicals are formed when iron reacts with an unsymmetrical endo-peroxide bridge in two different ways (Fig. 4) [18, 28].

The activated artemisinins does the following functionsfree radical-mediated oxidative stress, covalent interactions with plasmodial vital biomolecules, inhibition of PfATP6, parasite membrane damage, interference with plasmodial mitochondrial functions, interference with heme detoxification pathway, alkylation of heme and other proteins, and inhibition of proteins (HRP II and HDP).

Nagasundaram et al. analyzed the binding affinity and efficacy between PfATP6 and artemisinin in the presence of L263D, L263E, and L263K mutations, and was observed that artemisinin binding affinity gets affected by these mutations [29]. The controversy on the important role of PfATP6 as a target for artemisinin in the parasite P. falciparum is supported by Arnou et al. as they were not able to demonstrate any inhibition by artemisinins [30].

\section{Artemisinin resistance}

The evidence suggests that the involvement of Kelch 13 (PfK13) protein as the mutation in the Kelch 13 protein is associated with delayed parasite clearance and is believed for the artemisinin resistance [31]. In a recent study [32], a protein located at a Kelch13-defined compartment was identified and inactivated eight of these proteins including Kelch13 make parasites resistant to ART, and parasites with inactivated Kelch13 displayed reduced hemoglobin
Fig. 4 Modes of action of the artemisinins

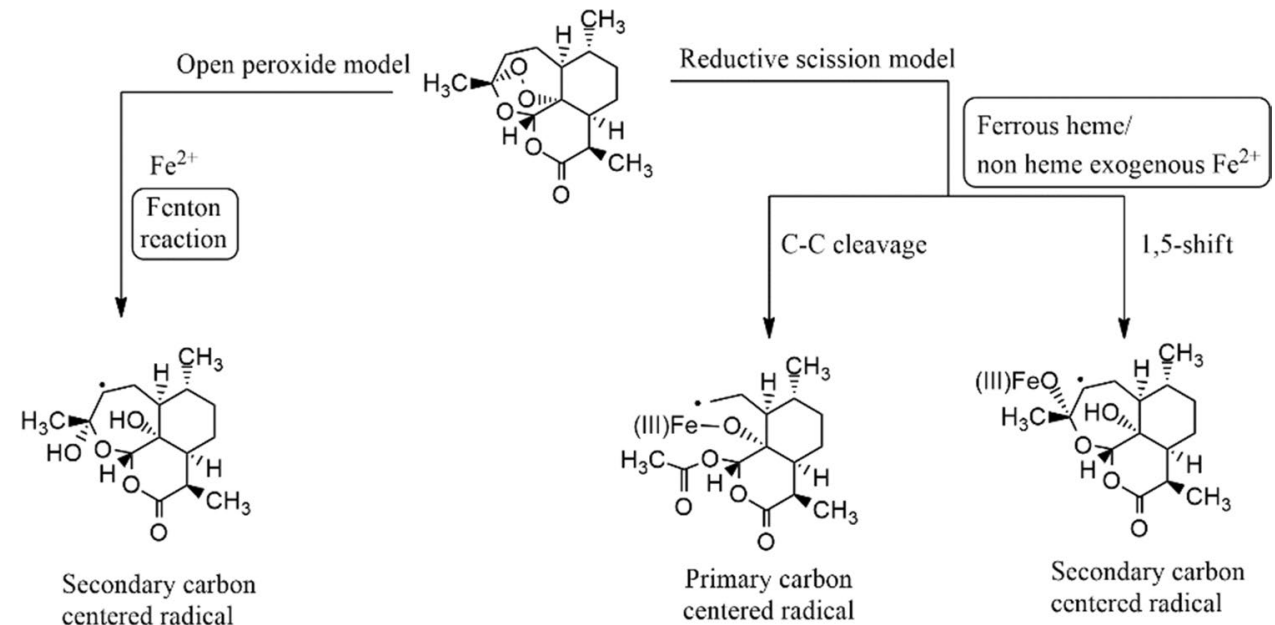


endocytosis resulting in parasite resistance. A perspective by Marapana et al. explains the malaria parasites produce heme by ingesting hemoglobin from the host red blood cell using cytosomes. The activation of the drug and parasite killing was caused by the interaction of heme in the parasite food vacuole with artemisinin. The uptake of hemoglobin by P. falciparum is regulated by PfKelch13-containing vesicles, which affect the amount of ART activation through reduced heme availability [33]. Siddiqui et al. in their study introduced 3D7 strain four Kelch13 (PfK13) mutations (C469Y, F446I, F495L, and N458Y) and characterized the in vitro artemisinin response phenotypes of the mutants. It was found that in the ring-stage survival assay (RSA) all parasites with PfK13 showed higher survival rates than in the control type. Only the mutation at N458Y showed a significantly higher RSA value (26.3\%) than in the control group. So, it can be said that mutation in P. falciparum PfK13 protein is associated with artemisinin resistance [34].

Giannangelo et al. [35] reviewed a paper on the antimalarial activity of ozonide in the context of artemisininresistant malaria. Since P. falciparum mutation is linked with the artemisinin resistance, the very short elimination half time of the artemisinin (about $1 \mathrm{~h}$ ) allows the resistant parasite to escape. On the other hand, antimalarial drug ozonide OZ277 and OZ439 have elimination half time of $3 \mathrm{~h}$ and 46-62 h, respectively and give sustained drug exposure profile (Fig. 5).

It is reported that absence of $\mathrm{K} 13$ gene mutation of $P$. falciparum among the artesunate/sulfadoxine-pyrimethamine treatment failures in southeast Sudan [36].

\section{Clinical trials}

Several clinical trials have been conducted to compare the safety and efficacy of artesunate and other anti-malaria drugs used to treat severe falciparum malaria.

One clinical trial, conducted in Thailand for 113 clinically severe falciparum malaria patients. It was found that the artesunate has a lower mortality rate than quinine (12\% vs. $22 \%$ ). Plasma lactate level, Glasgow coma scale score, and total serum bilirubin level were found to be independent risk factors for death. During artesunate therapy, fewer patients become hypoglycemic than in quinine (10\% vs. $28 \%, p=0.03$ ) [37].

In another open-label randomized controlled trial for patients admitted for severe falciparum malaria in hospitals across Bangladesh, India, Indonesia, and Myanmar. Intravenous (IV) artesunate was given $2.4 \mathrm{mg} / \mathrm{kg}$ body weight at 0,12 , and $24 \mathrm{~h}$ then daily $(n=370)$ or quinine (IV) $20 \mathrm{mg} / \mathrm{kg}$ infused over $4 \mathrm{~h}$ then $10 \mathrm{mg} / \mathrm{kg}$ infused over $2-8 \mathrm{~h}$, three times a day $(\mathrm{n}=731)$. Mortality in the artesunate is lesser than quinine ( $15 \%$ vs. $22 \%)$. Treatment with the artesunate is well tolerated, while that of quinine was associated with hypoglycemia, relative risk $3.2,1.3-7.8$, $p=0.009$ [38].

In another open-label, randomized clinical trial conducted in 11 centers in nine African countries, 5425 children ( $<15$ years) with severe falciparum malaria were randomly assigned for artesunate or quinine. Fewer people $8.5 \%$ in the artesunate have died than $10.9 \%$ in quinine treatment. The development of coma, convulsions, and deterioration of coma score all significantly less frequent in artesunate than in quinine. Post-treatment hypoglycemia was also less frequent in artesunate recipients than in quinine recipients ( $1.8 \%$ vs $2.8 \%, p=0.0134)$, and artesunate was well tolerated with no serious drug-related side effects [39].

In another randomized double-blind clinical trial between artesunate and artemether was conducted in Viet Nam in 370 adults with severe falciparum malaria. Artesunate arm was given $2.4 \mathrm{mg} / \mathrm{kg}$ then $1.2 \mathrm{mg} / \mathrm{kg}$ at $12 \mathrm{~h}$ and in $24 \mathrm{~h}$, where artemether arm was given $3.6 \mathrm{mg} / \mathrm{kg}$ then $1.8 \mathrm{mg} / \mathrm{kg}$ daily for at least $72 \mathrm{~h}$. The death rate was $7 \%$ vs. $13 \%, p=0.052$ in artesunate vs artemether. In the artesunate group, parasitemia declined more rapidly and both drugs were very well tolerated [40].

van der Pluijm et al. [41] studied a multicentre openlabel, randomized clinical trial for uncomplicated Plasmodium falciparum malaria, triple artemisinin-based combination therapies versus artemisinin-based combination therapies. Total 1100 patients were given either
Arterolane (OZ277)

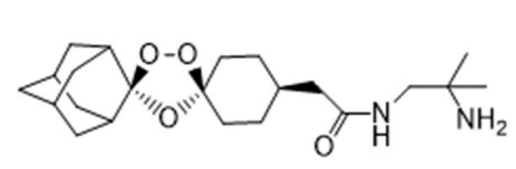

in vivo elimination half - life $=3 \mathrm{~h}$
DHA

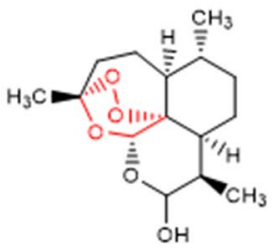

in vivo elimination half-life $<1.5 \mathrm{~h}$
Artefenomel (OZ439)

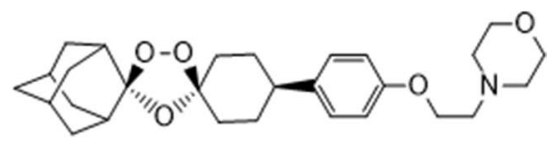

in vivo elimination half-life $=46-62 \mathrm{~h}$

Fig. 5 Arterolane, DHA, and artefenomel with their elimination half-life 
dihydroartemisinin-piperaquine plus mefloquine [269 $(25 \%)]$, artemether-lumefantrine plus amodiaquine [286 (26\%)], dihydroartemisinin-piperaquine [183 (17\%)], artesunate-mefloquine [73 (7\%)], or artemether-lumefantrine $[289(26 \%)]$. They found that artemether-lumefantrine plus amodiaquine and dihydroartemisinin-piperaquine plus mefloquine triple artemisinin-based combination therapies are well tolerated, efficacious, and safe to treat uncomplicated $P$. falciparum malaria including areas with artemisinin and artemisinin-based combination therapies partner drug resistance.

\section{Anticancer properties}

Besides antimalarial activity, artesunate, other artemisinins, and ART-hybrid also possess profound cytotoxic activity against tumor cells [42-47]. Recently, Li et al. reviewed a paper about artemisinins against hematological malignancies [48]. Artemisinin combination therapy (ACT) also works as anticancer agents such as there is evidence that exertion of a synergistic anti-tumor effect on non-small cell lung cancer by the combination of artesunate and carboplatin [49].

\section{Mechanism of action}

Figure 6 illustrates how artemisinin (ART) acts as an anticancer agent. Rather than free iron, heme is the primary activator of artemisinin. After activation, ART goes through multiple signaling pathways such as ROS generation, promiscuous protein alkylation, and DNA damage that affect multiple pathways and cellular functions lead to cancer cell death including apoptosis, ferroptosis, necroptosis, and other anti-cancer effects such as cell cycle arrest, anti-angiogenesis, anti-metastasis, etc (Fig. 6) [50].
The cellular response of artemisinin and its derivatives include oxidative stress, DNA damage and repair, and various modes of cell death.

\section{Oxidative stress}

Oxidative stress response was occurred by reactive oxygen species (ROS) and nitric oxide. It was found that in the rat model of colorectal cancer, artesunate suppresses inflammation and oxidative stress [51]. Wang et al. reported that artesunate sensitizes ovarian cancer cells to cisplatin by down-regulating RAD51 [52].

\section{DNA damage and repair}

The DNA damage and repair include base excision repair, homologous recombination, non-homologous end-joining. Fei et al. reported the enhancement of radiosensitivity of esophageal cancer cells with artesunate by inhibiting the repair of DNA damage. They found that artesunate upregulates P21 and down-regulates expression of cyclin D1, RAD51, RAD54, Ku70, and Ku86 protein of irradiated TE-1 cells [53]. Li et al. reported that DNA double-strand breaks that were induced by artesunate are repaired by the homologous recombination and non-homologous end-joining pathways [54].

\section{Cell death modes}

Various types of cell death modes can occur by artemisinins and those are apoptosis, autophagy, ferroptosis, necrosis, necroptosis, and oncosis.

Jia et al. reported, with the help of flow cytometry and western blot analysis that artemisinin triggered cytochrome

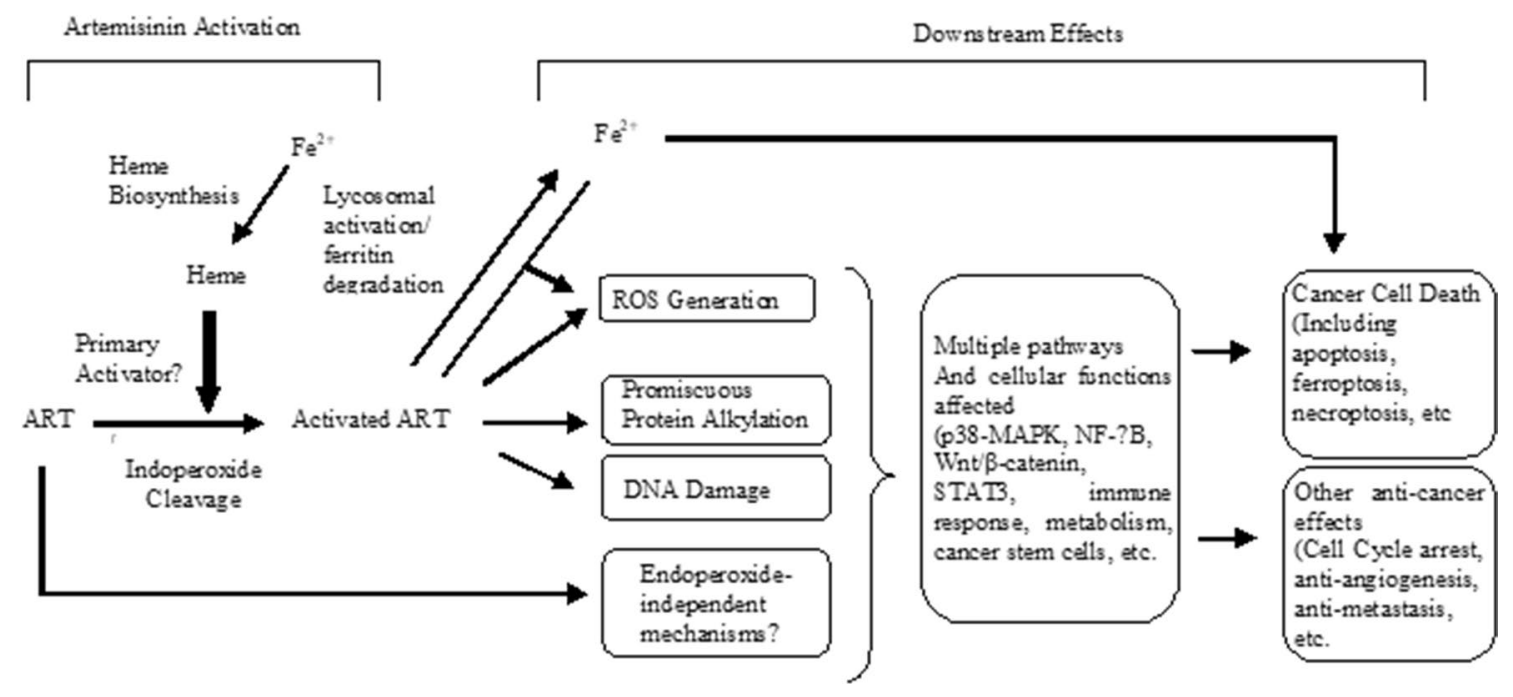

Fig. 6 General scheme of the mechanism of action of artemisinin (ART) in cancer 
Fig. 7 Molecular targets and signaling pathways that involve in the regulations of autophagy by artemisinins

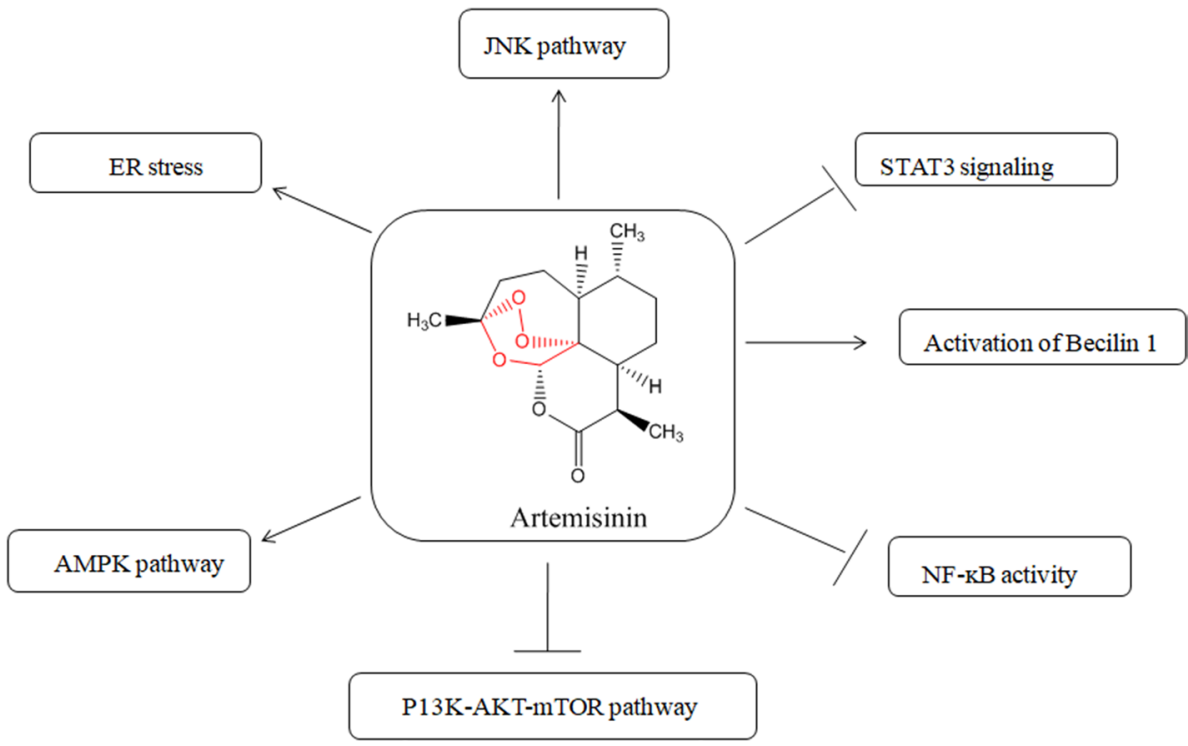

c release from the mitochondria into the cytoplasm, as a result, caspase-3-mediated apoptosis was activated [55]. Greenshields et al. reported that artesunate causes cell cycle arrest and apoptosis of triple-negative MDA-MB-468 and HER2-enriched SK-BR-3 breast cancer cells [56]. Cabello et al. reported that dihydroartemisinin (DHA) could serve as redox chemotherapeutic by selectively targeting melanoma cells but not primary melanocytes with the induction of NOXA-dependent apoptosis [57].

Figure 7 [58] illustrates the molecular targets and signaling pathways involved in the regulation of autophagy by artemisinins; AMPK stands for adenosine monophosphateactivated protein kinase; ER stands for endoplasmic reticulum; JNK stands for c-Jun NH2-terminal kinase; mTOR stands for mammalian target of rapamycin; NF- $\mathrm{kB}$ stands nuclear factor-kappa B; PI3K stands for phosphoinositide 3-kinase and STAT3 stands for signal transducer and activator of transcription.

Ferroptosis is driven by iron-dependent lipid peroxidation, which is a new form of programmed cell death and is distinct from regulated cell death such as apoptosis.

In a study, Chen et al. found that artemisinin can sensitize cancer cells to ferroptosis [59]. Wang et al. reported activating the ATF4-CHOP-CHAC 1 pathway, which affects ferroptosis in Burkitt's Lymphoma [60]. Li et al. reported synergization with sorafenib to induce ferroptosis in hepatocellular carcinoma [47].

\section{Modifications}

Several modifications of the artemisinin have been done to test their potency in anticancer properties. Their anticancer activities range from initiation of apoptotic cell death to inhibition of cancer proliferation, metastasis, and angiogenesis. They also work in the modulation of the cell signal transduction pathway [61].

The review by Gao et al. [45] focused on the hybrid molecule of artemisinin with other anticancer pharmacophores having potential anticancer properties and structure-activity relationships. The review includes hybrid molecules of artemisinin-chalcone hybrids, artemisinin-coumarin hybrids, artemisinin-ferrocene hybrids, artemisinin-phosphate hybrids, artemisinin-quinoline hybrids, artemisinin-steroid hybrids, and artemisinin-1,2,3-triazole hybrids. For example, an artemisinin-chalcone hybrid has $\mathrm{IC}_{50}$ values $0.09-23 \mu \mathrm{M}$

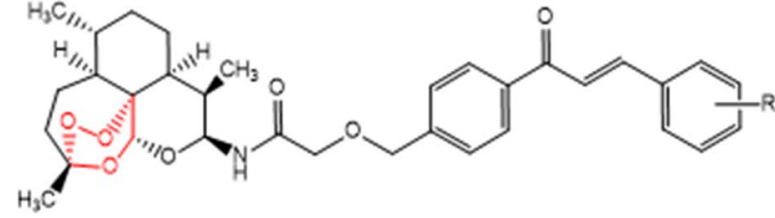

$\mathrm{IC}_{50}=0.09-23 \mu \mathrm{M}$

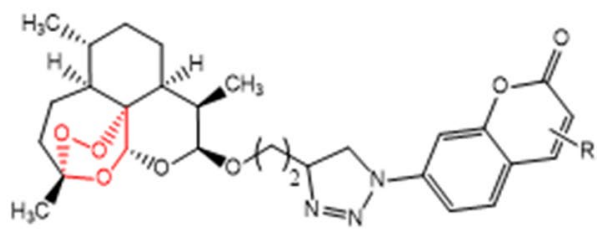

$\mathrm{IC}_{50}=0.01-95.74 \mu \mathrm{M}$

Fig. 8 Artemisinin-chalcone and artemisinin-coumarin hybrids 
which is no inferior to dihydroartemisinin $\left(\mathrm{IC}_{50}\right.$ : 5.6-15.6 $\mu \mathrm{M}$ ) against the five cancer cell lines (A549, H460, HeLa, HT-29, and MDA-MB-231) which states the significance of artemisinin-chalcone hybrids as an anticancer agent. Artemisinin-coumarin hybrids with $\mathrm{IC}_{50}$ values $0.01-95.74 \mu \mathrm{M}$ also showed promising activity against HT-29 and MDA-MB-231 cancer cell lines, where 1,2,3-triazole is favorable for the activity (Fig. 8).

$\mathrm{Hu}$ et al. [62] synthesized a series of compounds with artemisinin-indole and artemisinin-imidazole hybrids and tested them in vitro for four human cancer cell lines (A549, MCF-7, HepG-2, and MDA-MB-231) along with normal human hepatic cell (L02). Among them, two compounds shown in the figure have shown superior potency than artemisinin against MCF-7 (Fig. 9).

In another study, Botta et al. [63] synthesized a library of compounds obtained by coupling artesunate and dihydroartemisinin with a panel of phytochemical compounds. The hybrids and dimers were evaluated for their anticancer activities and were tested for cervical cancer cell lines and metastatic melanoma cancer cell lines. It was observed that hybrid compounds with eugenol and tyrosol, and one of the dimer compound shown in Fig. 10 has the most active cancer-selective properties.

Since the peroxide bridge present in artemisinins is the main pharmacophore responsible for both antiplasmodial
Fig. 9 Artemisinin derivatives with $\mathrm{IC}_{50}$ values for human cancer cell line MCF-7 cells

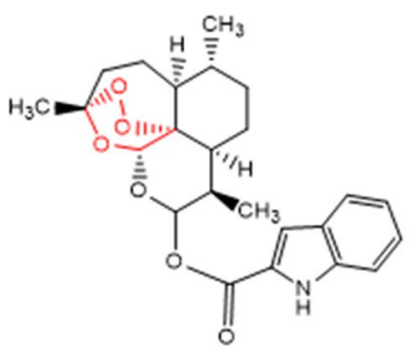

MCF-7 Cells

$\mathrm{IC}_{50}=6.78 \mu \mathrm{M}$

Artesunate

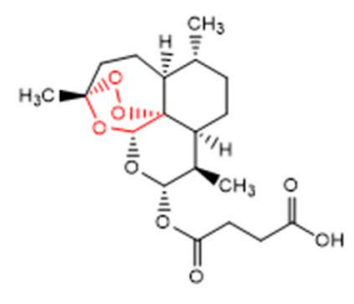

Antimelanoma Activity

Antimelanoma Activity SK-MEL3: $\mathrm{IC}_{50}=2.33 \mu \mathrm{M}$

SK-MEL3: IC $_{50}>300 \mu \mathrm{M}$

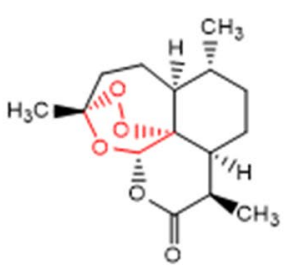

MCF-7 Cells

$\mathrm{IC}_{50}>50 \mu \mathrm{M}$

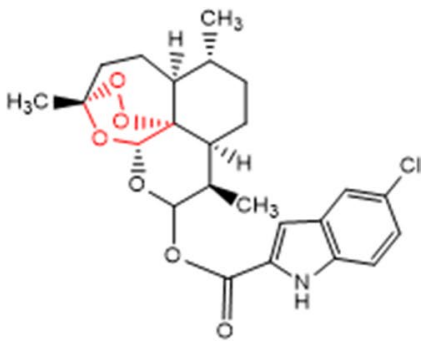

MCF-7 Cells

$\mathrm{IC}_{50}=5.25 \mu \mathrm{M}$

Dimer

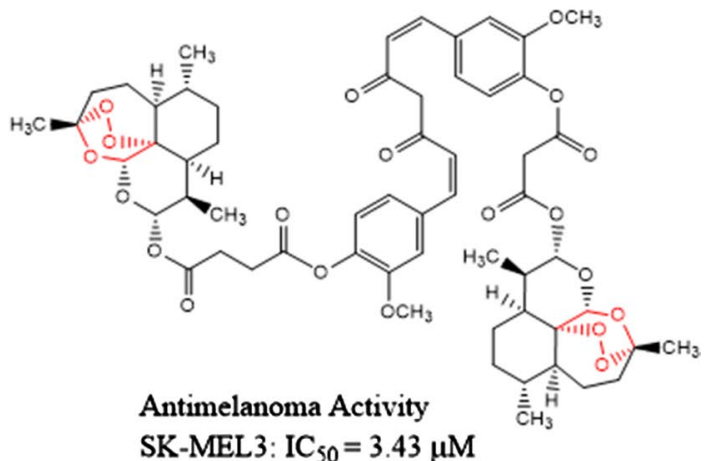

Fig. 10 Artesunate, hybrid, and dimer compounds with anticancer properties

Fig. 11 Artemisinin and 1,2,4-trioxane compounds for antimalarial and anticancer properties

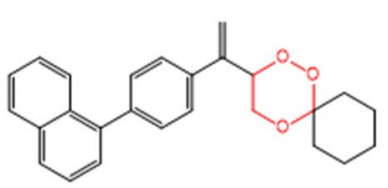

(a)

$\mathrm{IC}_{50}=1.65 \mu \mathrm{M}, \mathrm{SI}=10.96$

Lung Cancer (A549) Cell Lines

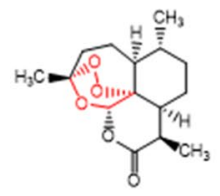

Artemisinin

$\mathrm{IC}_{50}=100 \mu \mathrm{M}$

Lung Cancer (A549) Cell Lines

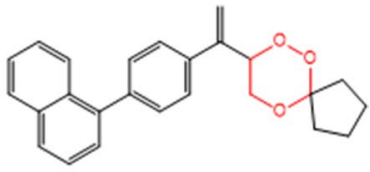

(b)

$\mathrm{IC}_{50}=3.36 \mu \mathrm{M}, \mathrm{SI}=0.23$

Lung Cancer (A549) Cell Lines 
as well as anticancer activities. Tiwari et al. synthesized a series of simple 1,2,4-trioxanes to test their potency of antimalarial and anticancer activities [64]. Out of several examples, the two most potent compounds (a) and (b) are listed in Fig. 11. The compound (a) with $\left(\mathrm{IC}_{50}=1.65 \mu \mathrm{M}\right.$, $\mathrm{SI}=10.96)$ has $>60$ fold in vitro more potency and the compound (b) with $\mathrm{IC}_{50}=3.36 \mu \mathrm{M}, \mathrm{SI}=0.23$ ) showed about 30 fold in vitro more potency in comparison to artemisinin $\left(\mathrm{IC}_{50}=100 \mu \mathrm{M}\right)$ against lung (A549) cancer cell lines. The compound (b) with $\left(\mathrm{IC}_{50}=0.059 \mu \mathrm{M}, \mathrm{SI} \geq 56\right.$ showed $>9$-fold more in vitro plasmodial activity in comparison to chloroquine $\left(\mathrm{IC}_{50}=0.546 \mu \mathrm{M}, \mathrm{SI}=36.6\right)$.

In another study [65], glycoconjugate derivatives of artemisinic acid were synthesized and anticancer properties were studied. It was found that all artemisinic acid glycoconjugates were able to inhibit the growth of MCF7, however, showed moderate cytotoxicity (Fig. 12).

\section{Other activities}

Along with antimalarial and anticancer properties, artemisinins also show activity against viral infections including SARS-CoV-2.

Artemisinins are effective against human cytomegalovirus, bovine viral diarrhea virus, and hepatitis $C$ virus. Flobinus et al. studied the stability and antiviral activity of artemisinin derivatives against human cytomegalovirus. The study has demonstrated that the dihydroartemisinin displayed a lower activity than artesunate, while artemisinin shows no activity [66]. Oiknine-Djian et al. studied artemisinin derivative artemisone as a potential inhibitor of human cytomegalovirus replication. It was found that the antiviral efficacy of artemisone was $\geq 10$-fold superior to that of artesunate in human foreskin fibroblast, lung fibroblasts, and epithelial cells [67]. Romero et al. studied the antiviral effect of artemisinin and a combination of drugs against bovine viral diarrhea virus (BVDV). It was found that IFN-alpha, ribavirin, and artemisinin reduced BVDVinduced cell death in the treatment of infected cells [68]. It has been reported by Paeshuyse et al. that artemisinin also inhibits hepatitis $C$ virus replicon replication [69].

Artemisinin, its derivatives, and artemisinin-based combination therapy (ACT) have been studying as potential antiSARS-CoV-2 (COVID-19) drugs [70-73]. Gendrot et al. reported artesunate-mefloquine, artesunate-pyronaridine, artesunate-amodiaquine, dihydroartemisinin-piperaquine, or artemether-lumefantrine showed antiviral inhibition against SARS-CoV-2 in vitro [74]. In another in vitro study, both artesunate and dihydroartemisinin showed similar antiSARS-CoV-2 potential with $\mathrm{EC}_{50}$ values of $12.98 \pm 5.30 \mu \mathrm{M}$ and $13.31 \pm 1.24 \mu \mathrm{M}$, respectively [70].

Besides antimalarial, anticancer, and antiviral properties, artemisinins are also effective against schistosomes-hemoglobin degrading pathogen [75], ocular diseases [76], and in inflammations [77].

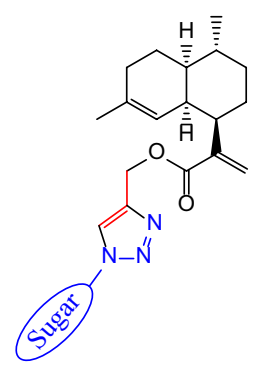

12-O-Artemisinic acid-glycoconjugates
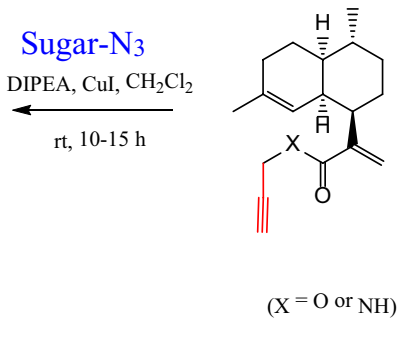

$(\mathrm{X}=\mathrm{O}$ or $\mathrm{NH})$

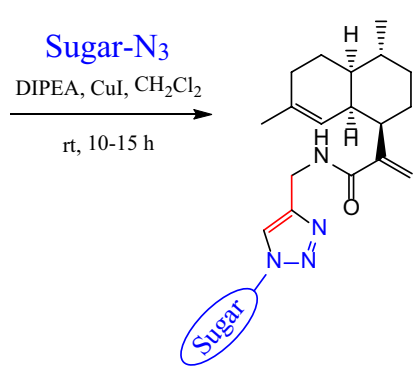

12- $N$-Artemisinic acid-glycoconjugates

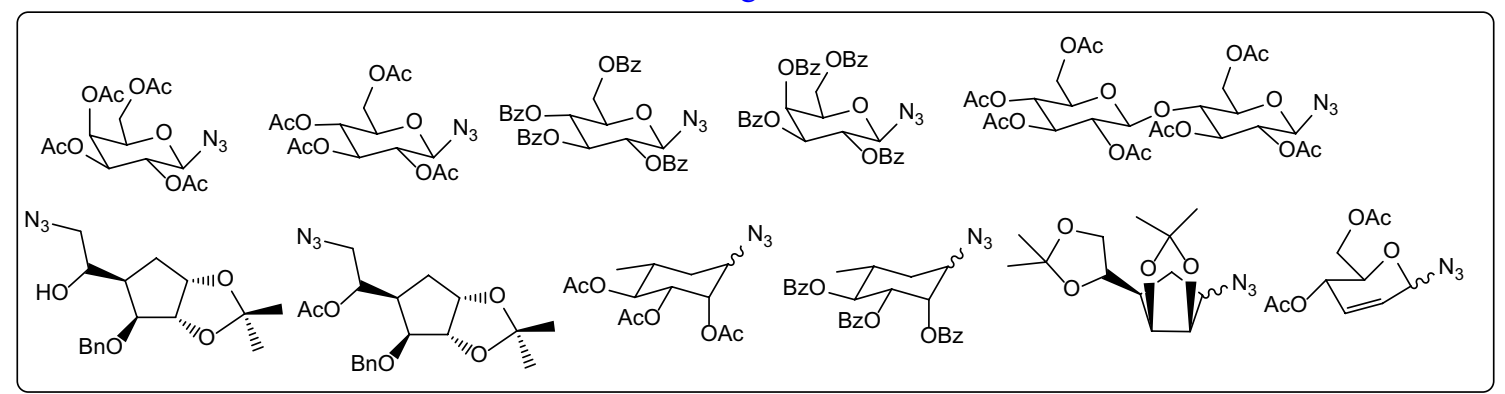

Fig. 12 Glycoconjugate derivatives of artemisinic acid for anticancer properties 


\section{Conclusion}

The Artemisia annua has been using as a source of the malarial drug since ancient times. At present, artemisinin and its derivatives are prepared industrially in a semi-synthetic way. The 1,2,4-endoperoxide bridge of artemisinins is responsible for its antimalarial activity. It was found that mutation at Kelch13 protein of P. falciparum is the root cause of ART-resistance. Clinical trial data published on the literature showed that the artesunate is more favorable than quinine or artemether to treat severe falciparum malaria. Artemisinins also show some activity against certain cancer cells. Oxidative stress, DNA damage and repair, and various types of cell deaths are the main mechanism of action in how artemisinins work as anticancer drugs. Besides antimalarial and anticancer activities, artemisinins are beneficial in viral diseases, schistosomiasis, ocular diseases, inflammations, and respiratory problems.

\section{References}

1. Klayman DL (1985) Science 228:1049

2. Su XZ, Miller LH (2015) Sci China Life Sci 58:1175

3. Kontogianni VG, Primikyri A, Sakka M, Gerothanassis IP (2020) Magn Reson Chem 58:232

4. Efferth T (2017) Semin Cancer Biol 46:65

5. Martino E, Tarantino M, Bergamini M, Castelluccio V, Coricello A, Falcicchio M, Lorusso E, Collina S (2019) Future Med Chem $11: 1443$

6. Zanetti A, Chaumont-Olive P, Schwertz G, de Oliveira MN, Gomez Fernandez MA, Amara Z, Cossy J (2020) Org Process Res Dev 24:850

7. Webster HK, Lehnert EK (1994) Trans R Soc Trop Med Hyg $88: 27$

8. Varela K, Arman HD, Yoshimoto FK (2020) J Nat Prod 83:66

9. Acton N, Roth RJ (1992) J Org Chem 57:3610

10. Zhu C, Cook SP (2012) J Am Chem Soc 134:13577

11. Turconi J, Griolet F, Guevel R, Oddon G, Villa R, Geatti A, Hvala M, Rossen K, Göller R, Burgard A (2014) Org Process Res Dev 18:417

12. Presser A, Feichtinger A, Buzzi S (2017) Monatsh Chem 148:63

13. World Malaria Report (2019) World Health Organization. https:// apps.who.int//iris/bitstream/handle/10665/330011/9789241565 721-eng.pdf. Accessed 18 Mar 2021

14. Achan J, Talisuna AO, Erhart A, Yeka A, Tibenderana JK, Baliraine FN, Rosenthal PJ, D'Alessandro U (2011) Malar J 10:144

15. Tiwari MK, Chaudhary S (2020) Med Res Rev 40:1220

16. Dondrop AM, Day NPJ (2007) Trans R Soc Trop Med Hyg 101:633

17. Krishna S, Bustamante L, Haynes RK, Staines HM (2008) Trends Pharmacol Sci 29:520

18. O'Neill PM, Barton VE, Ward SA (2010) Molecules 15:1705

19. Sun C, Zhou B (2016) Microb Cell 3:196

20. Checkley AM, Whitty CJM (2007) Expert Rev Anti Infect Ther 5:199

21. Green C, Quigley P, Kureya T, Barber C, Chizema E, Moonga H, Chanda E, Simfukwe V, Mpande B, Simuyuni D, Mubuyaeta K, Hugo P, van der Weije K (2019) Bull World Health Organ 97:810
22. Krieger J, Smeilus T, Kaiser M, Seo E-J, Efferth T, Giannis A (2018) Angew Chem Int Ed 57:8293

23. Bridgford JL, Xie SC, Cobbold SA, Pasaje CFA, Herrmann S, Yang T, Gillett DL, Dick LR, Ralph SA, Dogovski C, Spillman NJ, Tilley L (2018) Nat Commun 9:3801

24. Wang J, Huang L, Li J, Fan Q, Long Y, Li Y, Zhou B (2010) PLoS ONE 5:e9582

25. Bonepally KR, Takahashi N, Matsuoka N, Koi H, Mizoguchi H, Hiruma T, Ochiai K, Suzuki S, Yamagishi Y, Oikawa H, Ishiyama A, Hokari R, Iwatsuki M, Otoguro K, Mura SO, Kato N, Oguri H (2020) J Org Chem 85:9694

26. Ariey F, Ménard D (2019) Methods Mol Biol 2013:141

27. Meshnick SR, Thomas A, Ranz A, Xu C-M, Pan H-Z (1991) Mol Biochem Parasitol 49:181

28. Pandey N, Pandey-Rai S (2015) Protoplasma 253:15

29. Nagasundaram N, Doss CGP, Chakraborty C, Karthick V, Kumar DT, Balaji V, Siva R, Lu A, Ge Z, Zhu H (2016) Sci Rep 6:30106

30. Arnou B, Montigny C, Morth JP, Nissen P, Jaxel C, Moller JV, Maire ML (2011) Biochem Soc Trans 39:823

31. Tilley L, Straimer J, Gnadig NF, Ralph SA, Fidock DA (2016) Trends Parasitol 32:682

32. Birnbaum J, Scharf S, Schmidt S, Jonscher E, Hoeijmakers WAM, Flemming S, Toenhake CG, Schmitt M, Sabitzki R, Bergmann B, Fröhlke U, Mesén-Ramírez P, Blancke Soares A, Herrmann H, Bártfai R, Spielmann T (2020) Science 367:51

33. Marapana D, Cowman AF (2020) Science 367:22

34. Siddiqui FA, Boonhok R, Cabrera M, Mbenda HGN, Wang M, Min H, Liang X, Qin J, Zhu X, Miao J, Cao Y, Cui L (2020) MBio 11:e01134-e1219

35. Giannangelo C, Fowkes FJI, Simpson JA, Charman SA, Creek DJ (2019) Trends Parasitol 35:529

36. Abdel Hamid MM, Abdallah WME, Hussien M, Mohammed NM, Malik EM, Ahmed ME, Mohamed AO (2019) Trans R Soc Trop Med Hyg 113:428

37. Newton PN, Angus BJ, Chierakul W, Dondorp A, Ruangveerayuth R, Silamut K, Teerapong P, Suputtamongkol Y, Looareesuwan S, White NJ (2003) Clin Infect Dis 37:7

38. Dondrop A, Nosten F, Stepniewska K, Day N (2005) Lancet 366:717

39. Dondorp AM, Fanello CI, Hendriksen IC, Gomes E, Seni A, Chhaganlal KD, Bojang K, Olaosebikan R, Anunobi N, Maitland K, Kivaya E, Agbenyega T, Nguah SB, Evans J, Gesase S, Kahabuka C, Mtove G, Nadjm B, Deen J, Mwanga-Amumpaire J, Nansumba M, Karema C, Umulisa N, Uwimana A, Mokuolu OA, Adedoyin OT, Johnson WB, Tshefu AK, Onyamboko MA, Sakulthaew T, Ngum WP, Silamut K, Stepniewska K, Woodrow CJ, Bethell D, Wills B, Oneko M, Peto TE, von Seidlein L, Day NP, White NJ, AQUAMAT group (2010) Lancet 376:1647

40. Phu NH, Tuan PQ, Day N, Mai NT, Chau TT, Chung LV, Sinh DX, White NJ, Farrar J, Hien TT (2010) Malar J 9:97

41. van der Pluijm RW, Tripura R, Hoglund RM, Pyae Phyo A, Lek D, Ul Islam A, Anvikar AR, Satpathi P, Satpathi S, Behera PK, Tripura A, Baidya S, Onyamboko M, Chau NH, Sovann Y, Suon S, Sreng S, Mao S, Oun S, Yen S, Amaratunga C, Chutasmit K, Saelow C, Runcharern R, Kaewmok W, Hoa NT, Thanh NV, Hanboonkunupakarn B, Callery JJ, Mohanty AK, Heaton J, Thant M, Gantait K, Ghosh T, Amato R, Pearson RD, Jacob CG, Gonçalves S, Mukaka M, Waithira N, Woodrow CJ, Grobusch MP, van Vugt M, Fairhurst RM, Cheah PY, Peto TJ, von Seidlein L, Dhorda M, Maude RJ, Winterberg M, Thuy-Nhien NT, Kwiatkowski DP, Imwong M, Jittamala P, Lin K, Hlaing TM, Chotivanich K, Huy R, Fanello C, Ashley E, Mayxay M, Newton PN, Hien TT, Valecha N, Smithuis F, Pukrittayakamee S, Faiz A, Miotto O, Tarning J, Day NPJ, White NJ, Dondorp AM (2020) Lancet 395:1345

42. Chen S, Gan S, Han L, Li X, Xie X, Zou D, Sun H (2020) Ann Transl Med 8:767 
43. Yin S, Yang H, Zhao X, Wei S, Tao Y, Liu M, Bo R, Li J (2020) Hum Exp Toxicol 39:1681

44. Fröhlich T, Mai C, Bogautdinov RP, Morozkina SN, Shavva AG, Friedrich O, Gilbert DF, Tsogoeva SB (2020) ChemMedChem $15: 1473$

45. Gao F, Sun Z, Kong F, Xiao J (2020) Eur J Med Chem 188:112044

46. Wei S, Liu L, Chen Z, Yin W, Liu Y, Ouyang Q, Zeng F, Nie Y, Chen T (2020) J Cell Mol Med 24:276

47. Li ZJ, Dai HQ, Huang XW, Feng J, Deng JH, Wang ZX, Yang XM, Liu YJ, Wu Y, Chen PH, Shi H, Wang JG, Zhou J, Lu GD (2021) Acta Pharmacol Sin 42:301

48. Li Y, Shan NN, Sui XH (2020) Chin J Integr Med 26:947

49. Wang Z, Wang Q, He T, Li W, Liu Y, Fan Y, Wang Y, Wang Q, Chen J (2020) Clin Exp Pharmacol Physiol 47:1083

50. Wong YK, Xu C, Kalesh KA, He Y, Lin Q, Wong WSF, Shen HM, Wang J (2017) Med Res Rev 37:1492

51. Kumar VL, Verma S, Das P (2019) Drug Dev Res 80:1089

52. Wang B, Hou D, Liu Q, Wu T, Guo H, Zhang X, Zou Y, Liu Z, Liu J, Wei J, Gong Y, Shao C (2015) Cancer Biol Ther 16:1548

53. Fei Z, Gu W, Xie R, Su H, Jiang Y (2018) J Pharmacol Sci 138:131

54. Li PC, Lam E, Roos WP, Zdzienicka MZ, Kaina B, Efferth T (2008) Cancer Res 68:4347

55. Jia J, Qin Y, Zhang L, Guo C, Wang Y, Yue X, Qian J (2016) Mol Med Rep 13:4461

56. Greenshields AL, Fernando W, Hoskin DW (2019) Exp Mol Pathol 107:10

57. Cabello CM, Lamore SD, Bair WB 3rd, Qiao S, Azimian S, Lesson JL, Wondrak GT (2012) Invest New Drugs 30:1289

58. Sun X, Yan P, Zou C, Wong YK, Shu Y, Lee YM, Zhang C, Yang ND, Wang J, Zhang J (2019) Med Res Rev 39:2172

59. Chen GQ, Benthani FA, Wu J, Liang D, Bian ZX, Jiang X (2020) Cell Death Differ 27:242

60. Wang N, Zeng GZ, Yin JL, Bian ZX (2019) Biochem Biophys Res Commun 519:533

61. Lam NS, Long X, Wong JW, Griffin RC, Doery JCG (2019) Anticancer Drugs 30:1

62. Hu Y, Li N, Zhang J, Wang Y, Chen L, Sun J (2019) Bioorg Med Chem Lett 29:1138
63. Botta L, Filippi S, Bizzarri BM, Zippilli C, Meschini R, Pogni R, Baratto MC, Villanova L, Saladino R (2019) ACS Omega 5:243

64. Tiwari MK, Coghi P, Agrawal P, Shyamlal BRK, Yang LJ, Yadav L, Peng Y, Sharma R, Yadav DK, Sahal D, Wong VKW, Chaudhary S (2020) ChemMedChem 15:1216

65. Kotammagari TK, Paul S, Barik GK, Santra MK, Bhattacharya AK (2020) Org Biomol Chem 18:2252

66. Flobinus A, Taudon N, Desbordes M, Labrosse B, Simon F, Mazeron MC, Schnepf N (2014) J Antimicrob Chemother 69:34

67. Oiknine-Djian E, Weisblum Y, Panet A, Wong HN, Haynes RK, Wolf DG (2018) Antimicrob Agents Chemother 62:e00288-e318

68. Romero MR, Serrano MA, Vallejo M, Efferth T, Alvarez M, Marin JJ (2006) Planta Med 72:1169

69. Paeshuyse J, Coelmont L, Vliegen I, Van Hemel J, Vandenkerckhove J, Peys E, Sas B, De Clercq E, Neyts J (2006) Biochem Biophys Res Commun 348:139

70. Cao R, Hu H, Li Y, Wang X, Xu M, Liu J, Zhang H, Yan Y, Zhao L, Li W, Zhang T, Xiao D, Guo X, Li Y, Yang J, Hu Z, Wang M, Zhong W (2020) ACS Infect Dis 6:2524

71. Cheong DHJ, Tan DWS, Wong FWS, Tran T (2020) Pharmacol Res 158:104901

72. Sehailia M, Chemat S (2020) J Biomol Struct Dyn 22:1

73. Uzun T, Toptas O (2020) Chin Med 15:54

74. Gendrot M, Duflot I, Boxberger M, Delandre O, Jardot P, Le Bideau M, Andreani J, Fonta I, Mosnier J, Rolland C, Hutter S, La Scola B, Pradines B (2020) Int J Infect Dis 99:437

75. Wu J, Wang X, Chiu FCK, Häberli C, Shackleford DM, Ryan E, Kamaraj S, Bulbule VJ, Wallick AI, Dong Y, White KL, Davis PH, Charman SA, Keiser J, Vennerstrom JL (2020) J Med Chem 63:3723

76. Lu BW, Xie LK (2019) Int J Ophthalmol 12:1793

77. Kim SK, Choe JY, Park KY (2019) Biochem Biophys Res Commun 517:338

Publisher's Note Springer Nature remains neutral with regard to jurisdictional claims in published maps and institutional affiliations. 